\title{
Na gruzach widzenia. O prozie Jadwigi Stańczakowej
}

Monika Ładoń

TEKSTY DRUGIE 2021, NR 1, S. 138-154

DOI: 10.18318/td.2021.1.8 | ORCID: 0000-0000-7932-2728

Idę mroczną galerią w sobie ${ }^{1}$

W aham się, czy trzeba przedstawiać Jadwigę Stańczakową. Może nie tak dawne wydanie Dziennika we dwoje ${ }^{2}$ oraz tomu Haiku ${ }^{3}$ stanowi już wystarczającą rękojmię jej obecności w świadomości współczesnych czytelników. Z jednej strony - jeśli do przywołanych utworów dodamy jeszcze ważny film Parę osób, maty czas ${ }^{4}$ - zasadne wydaje się twierdzenie, że istotnie mamy do czynienia z rosnącym zainteresowaniem osobą Stańczakowej. Z drugiej jednak - zważywszy na wciąż nieliczne ślady recepcji jej utworów ${ }^{5}$ - wątpliwości budzi udział

1 J. Stańczakowa Magia niewidzenia, Czytelnik, Warszawa 1984, s. 21.

2 J. Stańczakowa Dziennik we dwoje, Warstwy, Wrocław 2015.

3 J. Stańczakowa Haiku, Warstwy, Wrocław 2015.

4 Parę osób, mały czas, reż. A. Barański, 2005.

5 Mam na myśli niedostatek tekstów o charakterze historycznoliterackim. Odnotowuję trzy ważne: A. Frania „Nie widzę i opisuję". Refleksje 
twórczości Stańczakowej w porządku historii literatury. Te dwie kategorie zatem - coraz wyraźniej rozpoznawalna osoba i rzadko interpretowane dzieła - zdają się fundamentem, na którym opiera się funkcjonowanie pisarki w czytelniczej świadomości. Niniejszy tekst pomyślany jest jako przedstawienie możliwych sposobów lektury utworów Stańczakowej, jako prezentacja wybranych pryzmatów patrzenia na nią - i piszę to, mając pełną świadomość, że słowa dotyczą niedowidzącej, a ostatecznie niewidomej poetki. Eksponuję tę figurę badawczego spojrzenia ze względu na znaczenie, jakie wzrok ma dla autorki Ślepaka - wszystko wszakże jest u niej wzrokocentryczne, każdy obraz staje się „ekwiwalentem widzenia”, a ona sama nawykowo patrzy i wytwarza widzialność, nawet wtedy, gdy nie widzi.

\section{W pryzmacie Mirona}

Nie sposób nie zacząć od okoliczności, która znacząco kształtuje obraz Stańczakowej, to znaczy od mentora, przyjaciela, współautora jej dziennika Mirona Białoszewskiego. Przegląd powstałych w ostatnim czasie tekstów popularyzujących sylwetkę pisarki ${ }^{6}$ uświadamia, że nie ma publikacji, które mogłyby przemilczeć inspirację, jaką autor Pamiętnika z powstania warszawskiego stanowił w życiu Stańczakowej. Trudno oczywiście negować rzeczywistą rolę Białoszewskiego w rozwoju twórczej drogi Stańczakowej, ale też łatwo chyba o impas, który polegałby na zawłaszczeniu pisarki przez Białoszewskiego. Skazywałoby to ją nie tylko na wieczny cień mistrza, bycie uczennicą i kopią zarazem, ale i na lektury przedsiębrane w kontekście nauczyciela, a to z pewnością zbliżałoby się do opresji. Miejsce Stańczakowej wyznaczałaby wówczas recepcja Białoszewskiego, odczytanie jej dzieł zależałoby, przynajmniej w jakimś stopniu, od interpretacji jego twórczych działań.

o twórczości Jadwigi Stańczakowej, „Inter-. Literatura - Krytyka - Kultura” 2018 nr 317, https:// pismointer.wordpress.com/numery-archiwalne/nr-317-2018/arkadiusz-frania-nie-widze-iopisuje-refleksje-o-wierszach-jadwigi-stanczakowej/ (dostęp: 1.05.2020); M. Ładoń „Ćwiczę widzenie”. O twórczości Jadwigi Stańczakowej, "Poznańskie Studia Polonistyczne” 2018 nr 32 (52); T. Czerska Dzienniki podwójne, czyli o kanibalizmie w diarystyce (Michaił i Jelena Bułhakowowie, Jadwiga Stańczakowa i Miron Białoszewski), w: tejże Diarystki: tekst i egzystencja, Wydawnictwo Naukowe Uniwersytetu Szczecińskiego, Szczecin 2018.

6 Zob. np. A. Kopkiewicz Sprawy babskie iślepackie ,"Dwutygodnik” $2015 \mathrm{nr} 11$ (172), https://www. dwutygodnik.com/artykul/6240-sprawy-babskie-i-slepackie.html (dostęp: 1.05.2020); T. Sobolewski Jadwiga Stańczakowa, pisarka, "Wysokie Obcasy” 28.01.2006 nr 4, https://www.wysokieobcasy.pl/wysokie-obcasy/1,96856,3132212.html (dostęp: 1.05.2020). 
Taka perspektywa wydaje się nieuchronna w przypadku Dziennika we dwoje, co najdobitniej wyartykułowała Tatiana Czerska. Badaczka, przyglądając się diarystycznemu dziełu pary Stańczakowa - Białoszewski, pytała, czy współautorstwo nie przypomina kanibalizmu: „Mamy przecież wówczas do czynienia z sytuacją nierówności, dominacji, podporządkowania, skolonizowania jednej osobowości twórczej przez drugą, bardziej znaczącą, dominującą poprzez przejmowanie energii, talentu, stylu, inspiracji"'. Trudno nie zgodzić się ze sposobem, w jaki szczecińska badaczka prezentuje Stańczakową: dostrzegając, że występuje „za plecami [Białoszewskiego], przygodnie”, stara się jednak ocalić jej autonomię - jako osoby i jako pisarki. „Myślę, że pora - konstatuje Czerska - aby twórczość Stańczakowej zacząć traktować jako samoistne zjawisko"8. Tyle że owa samoistność zawsze będzie coś poecie zawdzięczać: inspirującą rolę, ośmielenie twórcze, podpatrzony styl, technikę pisania. Intrygujący szkic Tatiany Czerskiej pozwala jednak w tym węźle odkrytych zależności i emocji prześledzić proces wybijania się Stańczakowej na niepodległość. Nawet jeśli przejście między statusem dziennikarki i pisarki stało się możliwe dzięki Białoszewskiemu, tomiki poetyckie ${ }^{9}$ oraz proza autofikcjonalna ${ }^{10}$ były wszak podpisywane jako dzieła kobiety. Sądzę zatem, że to im właśnie należy się szczególna uwaga, w nich bowiem można odnotować głównie (a może jedynie) akuszerską funkcję Białoszewskiego wobec tekstów Stańczakowej. Jakkolwiek lektura Dziennika we dwoje prowadzona równolegle do lektury Tajnego dziennika uwypukla wszelkie niuanse „sprzężenia pisarsko-biograficznego" - jak to nazywa Czerska - między Stańczakową a Białoszewskim", na

7 T. Czerska Dzienniki podwójne, czyli o kanibalizmie w diarystyce, s. 128.

8 Tamże, s. 142.

9 Stańczkowa debiutowała książkowo późno, jako sześćdziesięciolatka. Kolejno ukazały się tomy poetyckie: Niewidoma (Czytelnik, Warszawa 1979), Magia niewidzenia (PIW, Warszawa 1984), Depresje i wróżby (Czytelnik, Warszawa 1984), Na żywo (Czytelnik, Warszawa 1987), Ziemia-kosmos (Borgis, Warszawa 1990), Refugium (Borgis, Warszawa 1991), Japońska wiśnia. Haiku dla Michi Tsukada (Borgis, Warszawa 1992), Odwieczne drzewo (Borgis, Warszawa 1995). Warto wspomnieć jeszcze o dwóch tomach: Kabarecie Kizi-Mizi (nakładem autorki, Warszawa 1991) oraz Kabarecie Kizi-Mizi w locie (Borgis, Warszawa 1992), które silnie czerpią z Kabaretu Kici-Koci Białoszewskiego. Są to: Ślepak (Czytelnik, Warszawa 1982), Przejścia (PIW, Warszawa 1986) oraz Boicie się czarnego ptaka (PIW, Warszawa 1989).

11 Poza wspomnianą już aktywizującą rolą Białoszewskiego dla samego pisania Stańczakowej Czerska zwraca uwagę na niesymetryczność tego związku: protekcjonalne traktowanie poetki przez mistrza, niedocenienie z jego strony, a na przeciwległym brzegu - jej zaangażowanie, 
kartach kolejnych tomów poetyckich i wspomnieniowych Stańczakowa mówi już własnym głosem. Przesunięcie akcentów w rozpoznaniu jej osobowości i poetyki wydaje mi się krokiem podstawowym.

\section{Spojrzenie tyflologiczne}

Inna optyka wiąże się z obecnością Stańczakowej w publikacjach pedagogicznych czy typowo tyflologicznych. Dość znamienne wydaje mi się, że pierwszą przeczytaną przeze mnie publikacją naukową o poetce był artykuł Małgorzaty Walkiewicz $^{12}$, pedagoga specjalizującego się w tyflopedagogice. Nakreślony przez nią portret Stańczakowej oparty jest tyleż na analizie jej tekstów, co na bezpośrednich spotkaniach z pisarką i wielogodzinnych rozmowach, które zsumowały się w opowieść o trudnym losie niewidomej, warsztacie jej pracy i szczęściu ufundowanym na twórczości. Jeśli w tym skrupulatnym i rzeczowym obrazie coś mnie niepokoi, to sposób sformułowania celu badawczego: "Głównym celem jest próba znalezienia odpowiedzi na pytanie, czy i dlaczego człowiek niepełnosprawny może być szczęśliwy"13. Uwiera zwłaszcza partykuła „czy", która, otwierając problematykę badań nad niepełnosprawnością, każe skonfrontować obraz niewidomej pisarki z modelami badań w ramach disability studies - możliwymi i pożądanymi. Postawione w ten sposób pytanie - z sugestią, że ślepota Stańczakowej mogłaby wykluczać, a z pewnością utrudniać szczęście - zdradza, jak często w studia nad niepełnosprawnością

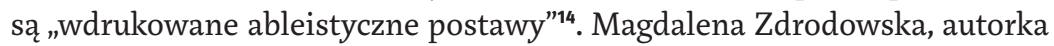
tekstu przedstawiającego historyczne i teoretyczne zaplecze disability studies, wskazywała na wartościujące, negatywnie nacechowane określenia w języku badaczy, które - używane i świadomie, i nieświadomie - dowartościowują „sprawną" perspektywę, jednocześnie poddając opresji osoby z niepełnosprawnością ${ }^{15}$. Podnoszę tę kwestię, by podkreślić, jak wyboiste okazują się

wiele praktycznych, codziennych czynności natury opiekuńczej, które wykonywała dla Białoszewskiego. T. Czerska Dzienniki podwójne, czyli o kanibalizmie w diarystyce, s. 140-145.

12 M. Walkiewicz Można być szczęśliwym, w: Trzy portrety. O kobietach radzących sobiez dysfunkcja wzroku, red. J. Kuczyńska-Kwapisz, Wydawnictwo APS, Warszawa 2004. Tamże, s. 91.

M. Zdrodowska Między aktywizmem a akademiq. Studia nad niepełnosprawnościq , "Teksty Drugie" 2016 nr 5, s. 393.

Rzecz oczywiście rozgrywa się nie tylko na płaszczyźnie języka, ale i regulacji prawnych, relacji społecznych czy działań instytucji; zob. tamże, s. 394-395. 
ścieżki disability studies - z jednej strony obnażają praktyki, które służą niekiedy do bezwolnego i bezrefleksyjnego uprzedmiotawiania niepełnosprawnych, a z drugiej uczą uważności i stawiają badaczom wysokie wymagania. Zakładam zatem, że w egzystencji i tekstach Stańczakowej zobaczyć trzeba nie pocieszycielski i pełen wdrukowanego optymizmu wariant losu osoby niewidomej, ale nakładające się na siebie formy wykluczenia, z którymi pisarka walczyła.

Z kolei Małgorzata Czerwińska, autorka imponujących rozmiarów książki „Stowem potrafię wszystko". O piśmienniczości osób z niepetnosprawnościa wzroku. Studium bibliologiczno-tyflologiczne, umieszcza Jadwigę Stańczakową w gronie 492 autorów z tego typu niepełnosprawnością. W takim kontekście pisarka jest jednak czymś więcej niż tylko elementem statystyki, chociaż jej dorobek na tle innych piszących z niepełnosprawnością wzroku okazuje się wcale nie najbogatszy, najpoczytniejszy czy najoryginalniejszy. Co ciekawe, nawet takie ujęcie, które ma przede wszystkim cele porządkujące, pozwala wysnuć kilka ważnych wniosków dotyczących funkcjonowania twórczości Stańczakowej w polskim piśmiennictwie. Z jednej strony autorka opracowania szuka w jej poezji i prozie „bogactwa wiedzy tyflologicznej”; czyta twórczość Stańczakowej jako prezentację świata niewidomych; docenia sposób, w jaki pisarka utrwala sytuację psychofizyczną i społeczną osób z niepełnosprawnością, ich przeżycia, doświadczenia, narastające stany depresyjne, codzienne trudności czy sposób odczuwania świata. Podkreśla przy tym zwyczajność i typowość przedstawień Stańczakowej, ale jest to perspektywa osób niewidzących. Z drugiej strony Czerwińska dowartościowuje te aspekty dzieła Stańczakowej, które zdają się oryginalne i fascynujące dla czytelników spoza grupy z niepełnosprawnością wzroku. Tutaj docenia to, że Stańczakowa niezwykle umiejętnie czyni z własnego niewidzenia zdystansowany przedmiot opisu, a z siebie - podmiotkę tekstów wykorzystującą różnorodne stany, by pokazać skrajności doświadczenia: od magii, wtajemniczenia w coś niezwykłego, przez sugestię „widzenia” po depresję ${ }^{16}$.

Warto ponadto zauważyć, że Czerwińska z dużą wrażliwością czyta i porządkuje dorobek piśmienny osób niewidzących, zwracając uwagę na wszelkie nieobiektywne kryteria ocen. Unika i gettoizacji autorów, i wartościowania ich dorobku przez pryzmat niepełnosprawności:

16 Zob. M. Czerwińska "Słowem potrafię wszystko". O piśmienniczości osób z niepełnosprawnościq wzroku. Studium bibliologiczno-tyflologiczne, Oficyna Wydawnicza Uniwersytetu Zielonogórskiego, Zielona Góra 2012, s. 226-227, 305-306. 
Niedopuszczalny jest brak obiektywnego uznania i oceny osiągnięć twórczych, aprobata dla zjawiska rzutowania upośledzenia osoby niepełnosprawnej na możliwości jej działania. Kryteria oceny powinny być jednakie dla twórców pełnosprawnych i tych z niepełnosprawnością. Pozbawienie równych szans to forma dyskryminacji. Dyskusyjną kwestią jest, iż niektórzy badacze, recenzenci, omawiając twórczość niepełnosprawnego wzrokowo autora, wiążą ją zbyt mocno, a więc stygmatyzująco, z rodzajem i stopniem niepełnosprawności. Nie jest to przekonująca współzależność. Stygmatyzacją jest odróżnianie twórczości pełnosprawnych od twórczości niepełnosprawnych przez obniżenie tym drugim poprzeczki. ${ }^{17}$

Czerwińska broni również pisarstwa osób z niepełnosprawnością wzrokową przed przecenianiem funkcji i kryteriów terapeutycznych, bo taki pryzmat wzmacnia według niej protekcjonalność. Autoterapia i kompensacja - mimo że obecne w dziele Stańczakowej - nie wyczerpują wszak złożoności jej tekstów poetyckich i prozatorskich, a to, co uznaje się za motywację, nie przekłada się przecież w całości na sens utworów - w takim wypadku należałoby bowiem wartościować teksty osób z niepełnosprawnościami nie ze względu za ich rzeczywiste znaczenie, ale ze względu na samą "dzielność” autorów ${ }^{18}$. W przypadku Stańczakowej ślepota wykorzystana jako impuls twórczy staje się też czynnikiem tożsamościowym, urasta do rangi fenomenu, wobec którego poetka potrafi się jednak zdystansować. Pochlebne głosy krytyków, doceniających m.in. kształt artystyczny, oryginalność poetyckiego obrazowania, mistrzostwo w imitowaniu mowy potocznej, autoironię, skłonność do miniatury czy celne pointy, pozwoliły Stańczakowej przekroczyć ograniczenia prasy dla niewidomych, w której - na co wskazują analizy Czerwińskiej - częściej dochodziło do uproszczeń, przeceniania

17

Tamże, s. 448.

Blisko w tym wypadku do kategorii inspiration porn, pojęcia wprowadzonego przez Stellę Young, która - jako aktywistka i dziennikarka - z perspektywy własnego wózka inwalidzkiego krytycznie oceniała reprezentacje osób niepełnosprawnych w codziennym i medialnym dyskursie, obdarzające je uznaniem jako osoby "dzielne”, "heroiczne”, "radzące sobie mimo przeciwności". Przekaz taki, kierowany do osób sprawnych, wzbudzał sprzeciw Young, dostrzegającej za tak źle pojętą inspiracją współczucie i litość: „Niepełnosprawność jest przedstawiana jako stan tak straszny, że wykonywanie nawet najprostszych, codziennych czynności urasta do rangi heroizmu. Już sama niepełnosprawna egzystencja czyni wyjątkowym"; zob. M. Zdrodowska Między aktywizmem a akademiq̨, s. 397. Zob. również M. Zdanowska Nie-złe upośledzenie, "Znak" 2017 nr 740. 
prosto pojętego biografizmu oraz wzmacniania funkcji terapeutycznej i rehabilitacyjnej19. Pamiętajmy, że Stańczakowej - istniejącej przecież w orbicie kółka, a później legendy Białoszewskiego - blisko było do czasopism opiniotwórczych, środowiskowych, nieograniczających się tylko do osób $\mathrm{z}$ niepełnosprawnością wzrokową ${ }^{20}$. Chociaż Czerwińska również pisze o roli Białoszewskiego w życiu Stańczakowej, to nie ocenia wpływu poety; polega raczej na zdaniu samej poetki, która wielokrotnie w wywiadach wspominała o inspiracji z jego strony, namowach do pisania czy wskazaniu zasadniczego tematu, czyli ślepoty ${ }^{21}$. Nie chcę zatem ani nie docenić, ani przecenić śladu, jaki Białoszewski odcisnął na twórczości Stańczakowej, sądzę jednak, że w tomach poetyckich i wspomnieniowych pisarka ukształtowała własną, oryginalną dykcję.

\section{Osoba z niepełnosprawnością / ślepa}

Interpretacja wybranych wątków tej prozy nie może jednak nie uwzględniać przywołanego już nurtu disabilty studies. Nie mam tutaj miejsca, by dokonać przeglądu różnorodnych definicji i przemian studiów nad niepełnosprawnością ${ }^{22}$, ważne wydaje mi się jednak wskazanie w tym polu badawczym kilku problemów, które wyznaczać mogą kierunki lektury tekstów Stańczakowej. Znamienne, że w jej utworach próżno szukać takich terminów, jak kaleka, inwalida czy niepełnosprawna. Pisarka tym samym poza nawias wyrzuca rozumienie swego stanu jako ograniczenia, braku, niemożliwości, niepełności, krytycy, a ich głosy publikowane były na łamach najważniejszych periodyków. Zob. np. M. Sołtysik Biała kredka, "Tygodnik Kulturalny” 1979 nr 22; J. Tarczałowicz Opis niewidzenia, "Życie Literackie" 1979 nr 20; M. Malessa Wchodzę w głąb barw " Nowe Książki” 1980 nr 9; R. Matuszewski Opis niewidzenia. Poezja, "Polityka” 1980 nr 9; A. Nasiłowska Widzenie poezjq, "Literatura” 1980 nr 5; P. Szewc Magia niewidzenia, "Twórczość” 1985 nr 6; M. Jentys /asnowidzenia, "Twórczość" 1988 nr 5; D. Ponińska Optymizm wyrosły z cierpienia, "Nowe Książki" 1990 nr 11.

Zob. M. Czerwińska „Słowem potrafię wszystko", s. 308-311, 317.

Zob. M. Czerwińska „Słowem potrafię wszystko”, s. 151-152.

Taką funkcję spełniają zresztą przywołany wcześniej tekst Magdaleny Zdrodowskiej oraz artykuły zebrane ostatnio W czasopismach: "Teksty Drugie” 2020 nr 2, "Czas Kultury” 2019 nr 4 (część numeru redagowana przez Arletę Galant i Macieja Dudę), "Annales Universitatis Paedagogicae Cracoviensis. Studia de Cultura” 2018 nr 10(1), "Fragile” 2017 nr 1 (35) czy „Znak” 2017 nr 740. Wszystkie one z powodzeniem uzupełniają białą plamę w polskich studiach nad niepełnosprawnością i nawet w ramach wstępnych przymiarek wyznaczają kierunki refleksji. 
słabości czy ułomności² ${ }^{23}$ Ten bagaż negatywnych skojarzeń, obecnych zarówno w słownikach, jak i w społecznym spojrzeniu, był początkowo związany z dwoma pierwszymi terminami, później jednak zaczął obciążać również najmłodszy z nich, czyli niepełnosprawność. Marzena Zdanowska, pisząc o założeniach ruchu disabilty pride, obnaża stereotypowe przekonanie, że niepełnosprawność musi oznaczać tragedię i ograniczenia nie do pokonania. Zmianę wnosiło definiowanie się jako „osoba z niepełnosprawnością” lub zaprzeczenie z doprecyzowaniem dysfunkcji: „nie jestem niepełnosprawny, jestem głuchy"24. Bez większego ryzyka można założyć, że oba stwierdzenia byłyby bliskie Stańczakowej. Pierwsze, ponieważ oznaczałoby zastąpienie

stanu całkowitej niemocy człowieka $[. .$.$] stwierdzeniem posiadania$ przez niego pewnej dysfunkcji. [...] Człowiek z niepełnosprawnością zostaje wyjęty spod normy tylko częściowo. To tylko chora ręka, noga, to tylko niezdolność motoryczna, a nie całościowa kwalifikacja wykluczająca człowieka z „normalnego" społeczeństwa. ${ }^{25}$

Stańczakowa przecież nie pomija swojej ślepoty, przeciwnie - czyni z niej atut, ale tak właśnie, by nie wykluczał jej z różnych sfer aktywności życiowych. Pisarka żyje zatem „z niepełnosprawnością”, która nie może się stać czymś wobec niej zewnętrznym, której nie może się pozbyć. Drugie stwierdzenie było bliskie Stańczakowej, bo właśnie podstawiona w miejsce głuchoty dysfunkcja pisarki stanowi centrum jej pisarstwa. Zdaje się, że Stańczakowa dzięki Białoszewskiemu - przekracza opresyjny charakter słów. Jej książkowy debiut poetycki nosi tytuł Niewidoma, a inicjalny liryk - na zasadzie kolejnego etapu identyfikacji - przywołuje słowo „ślepa”. Dialogiczna konstrukcja wiersza wprowadza na scenę bohatera, Wicka (maska Mirona). Właśnie on teatralizuje transformację podmiotki:

23 Pisała Joanna Hańderek: „Niepełnosprawność. Nie w pełni sprawny/sprawna, nie całkiem, niespełnienie, niedokończenie. W niepełnosprawności najbardziej ograniczające jest to «nie». Nie można, nie wolno, nie powinno się, nie da się. Słowo «nie» zabrania, wyznacza pewne pole możliwości, pewne ramy, poza które już wyjść nie można. [...] Słowo «nie» ma mocny wymiar ontologiczny, oznacza, że coś nie wydarza się albo nie istnieje. Oznacza brak, pustkę. Nie nie ma, nie jest. Brak bytu i działania. Wykasowanie, wymazanie", tejże, Niepełnosprawność?, "Fragile" $2017 \mathrm{nr} 1$ (35), s. 14. M. Zdanowska Nie-złe upośledzenie, s. 6.

25 J. Hańderek Niepełnosprawność?, s. 19. O kategoriach poddawanych niuansowaniu pisze także M. Zdrodowska Między aktywizmem a akademiqa, s. 399-401. 
Wicek mówi:

- Opera „Ślepa Jadzia w Caritasie”,

bo myślałem najpierw niewidoma,

ale to ma być dla tłumu,

więc musi być ślepa ${ }^{26}$.

Gradacja - od niewidomej przez ślepą do ślepaka, słowa opatrywanego słownikowym kwalifikatorem 'potoczny, a nawet pogardliwy', użytego jako tytuł pierwszego tomu wspomnien - nie prowadzą do deprecjonowania dysfunkcji kobiety ani przez nią samą, ani przez Białoszewskiego. „Sprawy ślepackie" pozostawały przecież w polu najżywszego zainteresowania autora Pamiętnika z powstania warszawskiego: nie tylko spacery Jadwigi z białą laską, ale i dosłowne wchodzenie w pozycję niewidomej. Białoszewski pomagał Stańczakowej oswoić stan dysfunkcji i jednocześnie dostrzec jej bieguny: przekonać, że ślepota może stać się osią tożsamości Stańczakowej/podmiotki jej tekstów, a także zaakceptować ją w codziennym wymiarze, pełnym trudów i rezygnacji, w jej zwyczajności. Dojrzewanie Stańczakowej do etykietek językowych, za którymi czaiła się opresja, wydaje się gestem tożsamościowym i emancypacyjnym, czymś w rodzaju „przewrotnego zawłaszczenia”, o którym pisała na przykładzie słowa „kaleka” Magdalena Zdrodowska:

W latach 70. wraz z włączeniem się niepełnosprawnych w walkę o prawa obywatelskie w Stanach Zjednoczonych i Wielkiej Brytanii termin cripple zaczął być używany przez osoby niepełnosprawne jako wyraz przynależności tożsamościowej. Używany był ironicznie lub wręcz prowokacyjnie, w odpowiedzi na przeszłe, opresyjne podejście do niepełnosprawności, ale także nowy, ugrzeczniony i politycznie poprawny język. Posługiwanie się tym terminem ma sztubacki, przekorny charakter. ${ }^{27}$

Patrzę tak na narracje Stańczakowej o losie osoby niewidomej, świadoma oczywistych różnic, ponieważ sądzę, że zgoda na tożsamość ślepaka i pisanie o niej - nawet jeśli zrodzona z podszeptu Białoszewskiego - była w istocie wyzwalająca. Przekonuje o tym na przykład sposób, w jaki pisarka przedstawia czas tracenia wzroku, który czytany z perspektywy disabilty studies mógłby nieść potencjał stopniowego odkrywania w sobie niepełnosprawności czy

26 J. Stańczakowa Lato, w: tejże Niewidoma, s. 7.

27 M.Zdrodowska Między aktywizmem a akademią, s. 401. 
wręcz wytwarzania niepełnosprawnego ciała. Tymczasem w prozie Stańczakowej mamy do czynienia z jednej strony z niezwykłą kondensacją opisu lat, na które przypada utrata wzroku, z drugiej - z ewidentnym przemilczaniem niektórych wątków związanych z tym doświadczeniem. Pierwszym takim wątkiem są sankcje medyczne, Stańczakowa bowiem bardzo rzadko pisze o swojej chorobie. Niedawno Arleta Galant postulowała, by odmedykalizować kulturowe reprezentacje niepełnosprawności i zdjąć z nich odium „chorowania"28 - tutaj ów gest wykonuje sama pisarka. Dysfunkcja nie jest w jej przypadku nagła; jest to rozłożony w czasie proces pogarszania się wzroku spowodowany przez konkretną jednostkę nozologiczną: retinitis pigmentoza, barwnikowe zwyrodnienie siatkówki. Dochodzenie do tożsamości osoby niewidomej ma u Stańczakowej charakter ambiwalentny - powolne tracenie wzroku dawałoby szansę na oswojenie i akceptację sytuacji, ale niepokojące symptomy są wypierane, a świadomość rozwijającej się choroby i jej konsekwencji jest niechciana, odrzucana. Symptomatyczny komentarz wieńczy wspomnienie przypadającego na czas okupacji badania w Klinice Dziecięcej przy Kopernika w Warszawie:

Badania były męczące. A potem pani doktor coś pisała, kreśliła. I podała mi dziwną kartkę. Dwa duże koła, w tych kołach maleńkie romby w centrum.

- To pani pole widzenia - powiedziała zafrasowana - jest bardzo wąskie.

- Dlaczego? - zapytałam.

- Z powodu choroby. [...]

Nie pytałam więcej. Nie chciałam wiedzieć. ${ }^{29}$

Odpychanie od siebie wiedzy o rozwoju choroby widać też w rytmie narracji, w której tylko sporadycznie, w niewielkich akapitach pojawia się postać słynnego okulisty profesora Ignacego Abramowicza i podsumowanie tego okresu: „Leczenie... ach, nie chcę do tego wracać, do operacyjnych zabiegów, do walki, którą profesor prowadził dla ocalenia resztek mego wzroku"30. Tocząca się batalia o widzenie pozostała czymś nieopisanym, w przeciwieństwie

28 Zob. A. Galant Literatura z niepełnosprawnościami. Zarys możliwych lektur, "Czas Kultury” 2019 nr 4, s. 42.

29 J.Stańczakowa Ślepak, s. 13. Tamże, s. 15. 
do uchwyconego przez Stańczakową życia na granicy dwóch światów: widzących i niewidzących.

\section{Nie(do)widzący świadek}

Symptomy postępującej choroby dostrzega już nastoletnia Stańczakowa, kiedy gubi się w blednących literach francuskiego tekstu, gdy gotycki drobny druk na lekcji niemieckiego przeraża ją swą nieczytelnością, a czoło pokrywają guzy po bolesnych spotkaniach ze skrzynką pocztową, latarniami, drzwiami: „Często się o coś uderzam, potykam. Już do tego przywykłam”"31, notuje. Stańczakowa z niefrasobliwością charakterystyczną dla młodego wieku oszukuje podczas badań wzroku, by lepiej wypaść, wstydzi się zleconych okularów (zresztą niepomagających), nie wiedząc, że pogorszenie wzroku jest wstępem do jego utraty. Ciekawe, że we wspomnieniach nie tyle bagatelizuje swój stan (co prawda nie zdaje sobie sprawy z jego powagi, ale nie unika opisów swej „niezdarności”), ile go mityzuje. Z tej swoistej fetyszyzacji wynika przeświadczenie, że już w młodzieńczych latach coś ją odgradzało od innych: „A we mnie jakiś cień. Smutek. [...] Złowróżbna ciemność. Nieokreślony lęk. Złe przeczucia" ${ }^{32}$.

Nie mogę jednak pominąć tego, że w przypadku młodości Stańczakowej mówimy o nakładających się formach wykluczenia, które piętrzą się, walcząc o niechciane pierwszeństwo. Utrata wzroku i stopniowe wyłączanie ze świata widzących przypadają bowiem również na czas wojny, izolację w getcie i tułaczkę między zmieniającymi się adresami po aryjskiej stronie. Stańczakowa, wspominając początek 1940 roku, pisze o swoim poczuciu nierealności:

Żyłam wtedy w zdumieniu i oszołomieniu. Dwie krańcowo odrębne rzeczywistości nakładały się na siebie - przyjazny dom, meble, obrazy, kwiaty w ogrodzie i groza wojny. Naloty, Niemcy, aresztowania. Wydawało mi się, że któraś z tych rzeczywistości jest nierealna. ${ }^{33}$

W tych warunkach rysująca się droga ku ślepocie wykluczała skupienie się na sobie, bo zdawała się nieuprawnionym egoizmem:

Tamże, s. 11.

32 Tamże. 
Kiedyś wieczorem szłam Wilanowską - wspomina Stańczakowa - Powoli, ostrożnie, krok za krokiem. Zapomniałam na chwilę o Niemcach, o bombardowaniach. O tym, że żyję z wyrokiem śmierci. Spojrzałam na gazową latarnię i pomyślałam - granatowy kwiat nocy. Bo ta latarnia prawie nie rozświetlała ciemności. Dla mnie już nie. Wojna. Okupacja. Czym są moje kłopoty z oczami wobec tego, co się dzieje dokoła? Wydaję się sobie niezdarna, śmieszna. ${ }^{34}$

Tyle że nie o nieporadność tutaj chodzi. Fragmenty wspomnień Stańczakowej z czasów wojny czytam zainspirowana kategorią świadka. Jakim świadkiem Zagłady jest Stańczakowa? Jakie znaczenie ma jej niedowidzenie? We wstępie do książki Świadek: jak się staje, czym jest? Agnieszka Dauksza pisała:

nie istnieje świadek obiektywny, niezaangażowany i bezstronny - zarówno cielesna obecność w miejscu wydarzeń, jak i sam akt świadczenia wymuszają przyjęcie określonej pozycji, zajęcie stanowiska: nawet zaniechanie czynności czy bezruch nie są tożsame z niebyciem, podobnie z odmową czy niemożnością przekazania świadectwa, które przecież także o czymś świadczą. ${ }^{35}$

Świadectwo Stańczakowej zatem wydaje mi się bezprecedensowe: jest ona uczestniczką wydarzeń, ale jej partycypowanie w świecie, o którym świadczy, zostaje zniekształcone przez osłabienie jednej z funkcji percepcyjnych. „Status świadka - pisze jednak Dauksza - niekonieczne zależy [...] od jego właściwości i kompetencji, nie zależy też od charakteru wydarzenia, o którym zaświadcza, ale od społecznych ram jego oddziaływania"36. Napisana wiele lat po wydarzeniach wojennych proza wspomnieniowa staje się „sensotwórczą ekspresją językową" i dzięki zastosowanej przez Stańczakową technice „małych narracji”, reporterskości i dialogowości oferuje efekt autentyzmu, którego nie sposób zakwestionować ani uznać za zmanipulowany. Modalność między świadkinią a jej świadectwem jest szczególnie intrygująca. Raz jeszcze Dauksza: „Chodzi z jednej strony o bezpośredniość uczestnictwa w wydarzeniu, autentyzm naoczności i namacalności tego doświadczenia,

34 J. Stańczakowa Ślepak, s. 12.

A. Dauksza Świadek: jak się staje, czym jest?, w: Świadek: jak się staje, czym jest?, red. A. Dauksza, K. Koprowska, Wydawnictwo IBL, Warszawa 2019, s. 8. 
z drugiej strony o ucieleśnioną, tkankową pamięć, która jest reaktywowana, uaktualniana i odgrywana w akcie świadczenia" ${ }^{37}$. Przypomnijmy, że Stańczakowa debiutuje książkowo późno, bo w wieku niemal sześćdziesięciu lat - pierwsza książka wspomnieniowa ukazuje się dopiero w roku 1982. Autentyzm i teraźniejszość zapisów nie mogą wszakże usunąć z pola widzenia faktu, że mamy do czynienia z pracą pamięci, sięganiem do wydarzeń przemilczanych i trudnych, do żydowskiego pochodzenia ${ }^{38}$. Dopiero przemiana Stańczakowej-dziennikarki w Stańczakową-pisarkę reaktywuje pamięć i daje materialne efekty.

W okupacyjnej rzeczywistości, w której jeden nieudolny gest, hałas, wyjście poza niewidzialność mogły przykuć uwagę Niemców czy szmalcowników, postępująca ślepota zmniejszała szanse Stańczakowej na przeżycie. Codzienne ryzyko związane z życiem w getcie, a później z jego opuszczeniem zostaje podwojone, choć jednocześnie można sądzić, że jest mniej wyraźne, a kontury zagrożenia rozmyte. Nieostre widzenie nie tyle jednak zatrzymuje Stańczakową po stronie nieświadomości zagrożeń, ile nasila lęk i maksymalizuje wysiłek przetrwania:

Wlepiłam oczy w drzwi. Ludzie kręcili się tam i z powrotem. W dymie i słabym świetle widziałam marnie. Mój wzrok, od lat nędzny, teraz sprawiał mi kłopoty. Zwłaszcza wieczorem. Potykałam się. Nabijałam sobie guzy. Błądziłam w tych przeklętych ciemnościach. Szczęście, że śnieg rozjaśniał ulicę. A może napięcie nerwów trzymało mnie. Bo jakimś

Tamże, s. 11.

Podczas debaty poświęconej Stańczakowej Anna Sobolewska, jej córka, i Justyna Sobolewska, jej wnuczka, mówiły o powrocie do czasów młodości, wojny i żydowskości: „Namysł nad okresem dzieciństwa, młodości, czasem okupacji, napisanie Ślepaka - to wszystko uobecniło sprawę żydowską. Niestety, było też polityczne uobecnienie. Wszystkich nas zaskoczył ponuro rok '68. Wtedy naprawdę wszyscy musieliśmy się w jakiś sposób określić. To był właśnie ten moment, kiedy te sprawy zaczęły być w domu na Hożej dyskutowane" [wypowiedź Anny Sobolewskiej]; „Był też stały lęk mojego pradziadka. Dla niego to była trauma. Jego nadopiekuńczość, jego fobie i manie, jego strach były związane właśnie z ukrytą tożsamością, bo on po wojnie był Franciszkiem Kotarbińskim, a przed wojną Adolfem Strancmanem. Zmienił też imię. Najpierw był Abramem, a ponieważ był kupcem, jeszcze przed wojną przyjął imię Adolf, bo było to dobre imię dla kupca. Cały czas się bał. Jadwiga uwalniała się od tego strachu, od tej nadopiekuńczości, co jest zresztą obecne w Dzienniku we dwoje. Ten strach to był właśnie strach poholokaustowy" [wypowiedź Justyny Sobolewskiej]. Zob. Stańczakowa sama i z Mironem [skrócony zapis rozmowy Anny Sobolewskiej, Justyny Sobolewskiej, Joanny Mueller-Liczner i Elizy Kąckiej], https://kulturaliberalna.pl/2015/og/o8/stanczakowa-sama-i-z-mironemskrocony-zapis-rozmowy/ (dostęp: 2.05.2020). 
cudem dotarłam bez potknięcia aż z Krochmalnej. I nie szukałam wejścia. Ktoś chudy i wysoki stanął w drzwiach. Wytężyłam wzrok. Tak. To on. ${ }^{39}$

Tak brzmi relacja z wyjścia z getta i spotkania z przyszłym mężem w kawiarni na Chłodnej. Właściwie niedowidzenie Stańczakowej urasta we wspomnieniach wojennych do rangi metafory żydowskiego losu, zwłaszcza kiedy sama pisarka podsumowuje po latach ten okres w następujący sposób: „Teraz wydaje mi się dziwne to całe krążenie wokół niedomkniętej pułapki. To niestaranne ukrywanie się, właściwie niemal bez lęku"40. Wojenna tułaczka po warszawskich i okolicznych adresach przypominała, w pewnym stopniu antycypowała błądzenie po omacku: ruch po kole, potknięcia, pułapki, konieczność zdania się na pomoc ludzi. Zarazem słabnąca zdolność Stańczakowej do uważnej obserwacji nie wykluczała bycia obserwowaną. Elżbieta Janicka, pisząc o kategorii obserwatora uczestniczącego, stwierdza:

Jednego możemy być pewni: patrzyli wszyscy. Wszelako to nie fakt patrzenia, lecz sposób patrzenia miał decydujący wpływ na los ofiar. To ów sposób stanowił "mur wokół muru” i sprawiał, że - jak wyraził się Jan Karski - „cała Polska była gettem”; śmiertelną pułapką bez wyjścia, bez zewnętrza. ${ }^{41}$

Patrzyli więc i na Stańczakową: „Pewnego dnia zauważyliśmy, że zezowata kelnerka przygląda mi się badawczo. Następnego dnia to samo"42. Spojrzenie kończy się denuncjacją i koniecznością zmiany mieszkania. Podobnie dzieje się przy wyprowadzaniu rodziców z getta, znów wszystko rozgrywa się w „oku policjanta”, którego spojrzenie wydobywa coś innego niż nieostry wzrok Stańczakowej: „Patrzę na rodziców. Starsza pani - niska, tęga, blond, szary kostium. Pan - przysadzisty, łysy, nijaki garnitur. Już bez opasek. Nie. Nie wyglądają. Tylko te twarze obojętne na siłę. [...] Nagle wyrasta przy nas granatowy policjant" ${ }^{\text {43 }}$. Opisów takich obserwacji i rozpoznań jest we

39 J. Stańczakowa Ślepak, s. 29-30.

40 Tamże, s. 51.

E. Janicka Obserwatorzy uczestniczq̨cy i inne kategorie. O nowy paradygmat opisu polskiego kontekstu Zagłady, w: Świadek: jak się staje, czym jest?, s. 40.

42 J. Stańczakowa Ślepak, s. 50. 
wspomnieniach Stańczakowej więcej - los jej rodziny rozgrywa się w spojrzeniach nieżydowskiej większości, które czasem - nawet jeśli są spojrzeniami Niemców - okazują się łaskawe. Innym razem jednak skazują na tułaczkę i wzmacniają lęk przed życiem z nową tożsamością. W tym sensie aryjska strona przypomina getto. Pisała Elżbieta Janicka:

Czujne oko nieżydowskiej większości było czymś w rodzaju gospodarskiego oka i sprawowało władzę, którą można nazwać władzą spojrzenia (franc. le droit de regard), prawem kontroli czy superwizji. Za sprawą tego mechanizmu getto nie potrzebowało murów. Natomiast tam gdzie mury istniały - jak w Warszawie - nie musiały być hermetyczne, ponieważ getto obowiązywało również po „aryjskiej” stronie. Getto było performatywem niezależnym od formalnych wyznaczników i terytorialnych delimitacji. Prawo spojrzenia zasadzało się na prawie do produkcji Żyda. Obserwator uczestniczący przywoływał dostrzeżonego/dostrzeżoną do żydostwa, jak się przywołuje do porządku. ${ }^{44}$

W perspektywie zarysowanej przez Elżbietę Janicką - okupowana Polska jako rzeczywistość panoptyczna na wzór Foucaultowskiego „aparatu wszechdyscyplinarnego"45 - Stańczakowa narażona jest na permanentne spojrzenie-pułapkę, którego nie może się ustrzec, również dlatego że sama z coraz większym trudem je dostrzega.

Jednocześnie z zapisków wspomnieniowych Stańczakowej przebijają niezwykle intensywne obrazy wojennego życia, przypadkowych spotkań z dawnymi żydowskimi przyjaciółmi pozostawionymi w getcie, których poetka nie unika, mimo że funkcjonuje już w ramach nowej tożsamości. Obrazy są tak przenikliwe, pełne szczegółów, że nie sposób uwierzyć, by powstały tylko w ramach licentia poetica, ale $\mathrm{z}$ drugiej strony pamięć diarystki zastanawia wiernością, żywością i autentycznością. Zdaje się, że trauma zapisuje się mimo gasnącego wzroku, a sugestywność doświadczeń okazuje się zbyt duża, by mogła ją przykryć zasłona zamglonego, nieostrego spojrzenia. Rację ma Marek Zaleski, który pisząc o formach pamięci w literaturze, zwracał uwagę na znaczenie splotu powtórzenia i opóźnienia: „Rzeczywistość, powracająca w pamięci, jawi się w powtórzeniu (i tym samym w opóźnieniu). Poprzez

44 E. Janicka Obserwatorzy uczestniczq̨cy i inne kategorie, s. 43-44.

45 Tamże, s. 44-45. Zob. także M. Foucault Nadzorować i karać. Narodziny więzienia, przeł. T. Komendant, Aletheia, Warszawa 2009. 
opóźnienie właściwe powtórzeniu to, co przedstawione, istnieje wy raźn i e j"46. Stańczakowa powtarza swe wojenne doświadczenia i w tym geście „rehabilitacji kaleczonej pamięci”, jak pisał Zaleski, widzi zdarzenia i siebie ostrzej, niż mogła wówczas.

„Wojna przecięła moje życie na to co przed i to co po niej.Po wojnie smutek wtopił się prawie całkowicie w tracenie wzroku, w coraz bledszy, niknący dla mnie świat"47, pisała w Ślepaku. W utrwalaniu tego, co zdarzyło się na „skraju widzenia” (koniec wojny, wyzwolenie w Lublinie, praca dziennikarska w Gdańsku, powrót do Warszawy), coraz bardziej odczuwalne są smutek i melancholia. Stańczakowa zauważa, że traci samodzielność: „Moja reporterska bieganina z potykaniem się o szramy chodników. Tylko wieczory złe, często się przewracam, tracę orientację. W końcu rezygnuję z samodzielności i co wieczór ktoś z rodziny przychodzi po mnie do redakcji" ${ }^{48}$. Na ten - jak można sądzić - bardzo dramatyczny czas życiowy przypadają nieudane operacje, trudna decyzja o macierzyństwie, śmierć matki, rozpad małżeństwa, wreszcie wymykająca się z rąk praca. Dotychczasowe niedowidzenie, dokuczliwe zazwyczaj wieczorem i noca, zamienia się w stan permanentny: „Kłopoty we dnie.Trudno mi przechodzić przez jezdnię. Nieznane ulice są jak labirynty. Wszędzie czyhają zasadzki. Blask słońca mnie oślepia. Z czytaniem coraz gorzej. I lupa mało pomaga"49. Kiedy czytam tego rodzaju fragmenty, brzmiące jak preludium ślepoty, dostrzegam, że utrata wzroku okazuje się dla Stańczakowej wyzwalająca, pozwala bowiem poetce na innych niż dotychczas prawach odzyskać samodzielność. Zaakceptowanie siebie jako kobiety niewidomej ma właściwie coś z doświadczenia transgresyjnego, chociaż wymaga przepracowania pierwszej fali rozpaczy: „Co będzie z dzieckiem - mówiłam - co będzie z moim życiem? [...] pamiętam, jak [Stach Madej, redaktor brajlowskiej «Pochodni»] przedstawił mnie jako niewidomą koleżankę na zebraniu Ligi Kobiet. To mną wstrząsnęło. Pierwszy raz skojarzyłam niewidomość ze sobą"50. Autobiograficzne opowieści Stańczakowej dalekie są od katalogów rezygnacji, przeciwnie - pisarka ukierunkowuje energię na nową jakość życia, które, jak sądzi, „daje się niemal bez granic rozbudowywać

\footnotetext{
46 M.Zaleski Formy pamięci, słowo/obraz terytoria, Gdańsk 2004, s. 7.

47 J. Stańczakowa Ślepak, s. 101.

48 Tamże, s. 14.

49 Tamże, s. 15. 
od środka”51. Doskonali się zatem w „sztuce życia bez wzroku”, dramat utraty zastępując optymizmem płynącym z możliwości, jakie otwierają się przed nią jako pisarką niewidomą ${ }^{52}$.

Z miejsca, do którego doprowadzam tekst poświęcony Stańczakowej, wyraźnie widać, ile impulsów badawczych dostarczyć może jej dorobek.

\section{Abstract}

\section{Monika Ładoń}

UNIVERSITY OF SILESIA (KATOWICE)

On the Ruins of Seeing: Jadwiga Stańczakowa's Prose

Ładoń portrays the blind journalist, poet and prose writer Jadwiga Stańczakowa (1919-1996), outlining the state of research on her work and presenting possible readings of her output - with a focus on the role of her mentor Miron Białoszewski, or in terms of literature with disabilities (also from a typhlological perspective). Ładoń explores Stańczakowa's memoirs Ślepak (Blind, 1982) as the story of a blind witness of the Holocaust.

\section{Keywords}

Jadwiga Stańczakowa, disability studies, blindness, witness

51 Tamże.

52 Tematowi tożsamości kobiecej i pisarskiej poświęciłam tekst Niewidoma kobieta, niewidoma pisarka. Tożsamości Jadwigi Stańczakowej, „Przestrzenie Teorii” 34, Poznań 2021 (w druku). 